\title{
Botanical Composition of Diets of Cattle Grazing South Florida Rangeland
}

\author{
R.S. KALMBACHER, K.R. LONG, M.K. JOHNSON, AND F.G. MARTIN
}

\section{Abstract}

The botanical composition of the diets of 5 esophageal-fistulated steers in summer (June to August) and winter (January to March) on a south Florida range was studied in order to point out those plants or groups of plants that warrant management. Diets of steers grazing 3 ecosystems were compared: pine palmetto (Typic and Arenic Haplaquod soils), fresh-water marsh (Terric Medisaprist soil), and transition area around the marsh (Spodic Psammaquent soil). In addition we wanted to know if diets of steers regrazing a summer-grazed pasture in the winter were the same as diets from a pasture grazed only in the winter. A total of 320 diet samples were analyzed microhistologically, and out of 109 species, steers were found to eat $\mathbf{4 2}$ species. Steer diets were significantly different between summer and winter, while diets were similar on the regrazed-winter and winter-only pasture. Differences between summer and winter diets were mainly a decrease in Panicum hemitomon on the marsh and a decrease in Lachnanthes caroliniana in the winter diets on the pine-palmetto area, an increase in the proportion of shrubs in the winter diet on the pine-palmetto area, and an increase in Xyris spp. and Solidago fistulosa in the latewinter on the marsh and the transition area around the pond. These diet changes were the result of changes in plant availability or palatability, which was the case with $P$. hemitomon. These data indicated that $A$ ndropogon spp. and Schizachyrium stoloniferum were major components of the pine-palmetto area diet of cattle and should receive management to increase their yields. Forbs, though seasonally available, should be encouraged by shrub control, careful use of selective herbicides, and promotion of natural reseeding. Shrubs, especially Serenoa repens and Ilex glabra should be available as winter foods.

Florida's southern range is primarily a flatwoods site, which is a broad flat area interspersed with 1 to 10-ha saucer-shaped depressions which form fresh-water marshes or maidencane (see Table 2 for Latin binomials) ponds. Hilmon (1964) described southern Florida rangeland and its vegetation, and indicated that the pinepalmetto ecological type comprised $75 \%$ of the range, and the fresh-marsh type made-up $15 \%$ of the range. The remaining $10 \%$ was in wet-prairie, which is a transition between pine-palmetto and fresh water marsh. As an important part of the total pasture system, range is frequently interfaced with improved pastures, and most ranching operations use range in the winter as a source of roughage for dry-pregnant cows (Kalmbacher 1978).

Unlike most cultivated pastures where 1 or 2 forages are grazed, range pastures often have over 100 indigenous plants from which livestock can select. Many range plants are available seasonally and others, while available throughout the year, are only eaten seasonally. Ranchers need to know which species cattle select in order to determine supplementation needs, make best use of different pastures, and manage important plants.

A review of literature pertaining to botanical composition of range cattle diets indicated certain generalities. First, out of a large number of available species, only a few made up the major portion

\footnotetext{
Authors are associate agronomist, Ona Research Center, Ona Fla. 33865; former graduate assistant, Department of Agronomy, University of Florida, Gainesville 32611; associate professor, School of Forestry and Wild life Management, Louisiana State University, Baton Rouge 70893; and associate statistician, Department of Statistics, University of Florida, Gainesville 32611.

This article is Florida Agricultural Experiment Paper No. 4220.

Manuseript received November 29, 1982.
}

of the diet (Beck 1975, Bishop et al. 1975, Rosiere et al. 1975, Uresk and Rickard 1976, Havstad et al. 1979). Second, on a year-round basis the perennial grasses were the mainstay of the diet (Thetford et al. 1971, Beck 1975, Bishop et al. 1975, Rosiere et al. 1975, Durham and Kothmann 1977, Havstad et al. 1979, Johnson and Pearson 1981). A third common finding was that the diet changed during the year. Forbs played an important role in spring or summer (Wallace et al. 1972, Beck 1975, Vavra et al. 1977, Havstad et al. 1979), and shrubs were consumed in the greatest amount during the winter (Galt et al. 1969, Durham and Kothmann 1977).

This study was designed to determine which plants should be favored by management by identifying forages serving as staples for cattle grazing south Florida range during summer and winter grazing seasons. Secondly, since range is frequently rotationally grazed, we wanted to determine if winter diets were the same on pasture grazed in the winter only vs. one grazed in the summer then regrazed in the winter.

\section{Materials}

The study was conducted at the University of Florida's Ona Agricultural Research Center in south-central Florida ( $27^{\circ} 35^{\prime} \mathrm{N}$, $\left.81^{\circ} 55^{\prime} \mathrm{W}\right)$. A 16.2 -ha native flatwoods pasture in good-toexcellent condition was divided into two 8.1-ha pastures: each containing 5.7 ha of pine-palmetto ecological area (Fig. 1); 1.6 ha of fresh-water marsh (Fig. 2); and 0.8 ha of transition, which was the area around the marsh (Fig. 3). These areas have been described by Hilmon (1964). Major soils on the pine-palmetto area were Ona and Smyrna fine sands (sandy, siliceous, hyperthermic Typic and Arenic Haplaquods, respectively). The soil on the marsh area was a Samsula muck (sandy, siliceous, silic-dysic, hyperthermic, Terric Medisaprist), and on the transition area, a Basinger fine sand (sandy, siliceous, hyperthermic, Spodic Psammaquent). All ecological areas in both pastures were burned in January 1980 . One pasture was grazed from 16 June to 26 August 1980 (referred to as 'summer pasture'), then regrazed between 15 January and 18 March 1981 (referred to as 'regrazed-winter pasture'). The second pasture was only grazed between 12 January and 15 March 1981 (referred to as 'winter-only pasture'). All cattle were removed between 26 August and 12 January 1981.

Four esophageal-fistulated, Brahman cross steers $(325 \mathrm{~kg})$ were used on the summer grazed pasture and 5 steers were used on the winter-only and regraze winter pastures. Fistulated cattle were corralled over-night and released at 0800 hours for a 15 minute collection (1.0 to $1.5 \mathrm{~kg}$ forage) period during which they were hazed to a different ecological area on each collection day. Upon return to the corral and removal of the screen-bottom collection bags, steers were given a supplment feed $(0.5$ and $1.0 \mathrm{~kg} / \mathrm{steer}$ in summer and winter, respectively) of $50 \%$ whole corn, $47 \%$ alfalfa pellet, $2.0 \%$ molasses, $1.0 \%$ mineral.' Fistulated steers were then released and upon being corralled in the evening ( 2000 hours summer, 1700 hours winter) were given the same amount of supplemental feed. Cattle had free access to minerals.'

Cattle were allowed to adjust to the pastures for a 2-week period before collections began. Collections were made every other day in the summer (16 June to 26 Aug. 1980) when 47 samples were collected from the steers grazing on the pine-palmetto area, 37

Ona Station Mineral No. 2. contains: Ca, 12\%, P, 12\%; $\mathrm{NaCl}, 25 \% ; \mathrm{Fe}, 1.0 \% ; \mathrm{Cu}$, $0.13 \% ; \mathrm{Co}, 0.03 \% ; \mathrm{Mn}, 0.05 ; \mathrm{Zn} 0.10 \% \mathrm{I}, 0.04 \% ; \mathrm{F}, 0.18 \%$. 


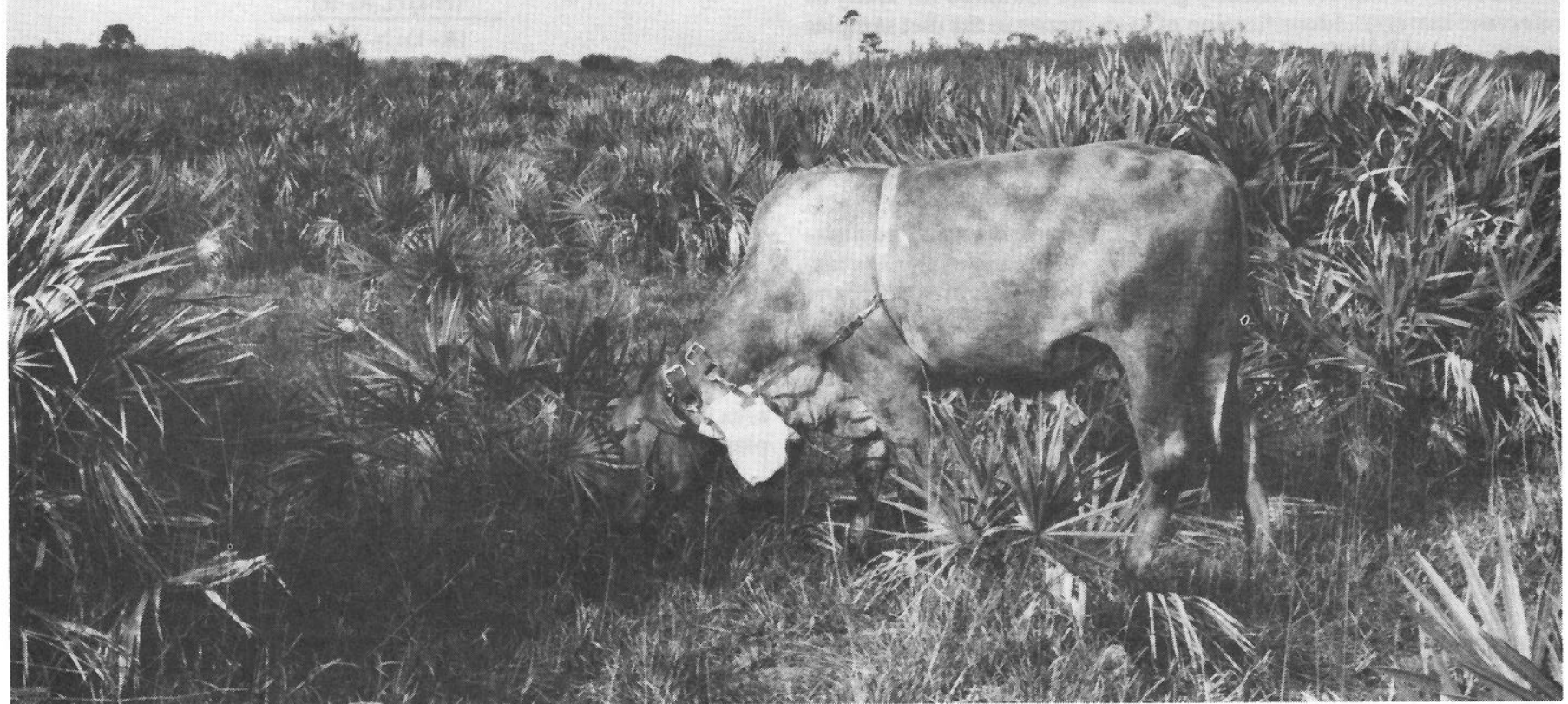

Fig. 1. Pine-palmetto ecological area on a South Florida flatwoods range near Ona.

from cattle grazing the marsh, and 17 from cattle grazing the transition area. Winter collections were made with the steers alternately on the winter-only and regraze-winter pastures. The 3 ecological areas were grazed on one pasture, then during the next 3 days, the 3 areas were grazed on the other pasture. There were 38 samples collected on the pine-palmetto area of the regraze-winter pasture, 36 samples on its marsh, and 37 samples on its transition area. On the winter-only pasture there were 36 samples collected on each of the 3 areas.

Additional nonfistulated steers were placed on the pasture to promote uniform grazing and provide additional grazing pressure. Moderate stocking rates (includes all cattle) for the summer, winter-regraze and winter-only pastures were 55,45 , and 53 animal unit grazing days/ha, respectively.

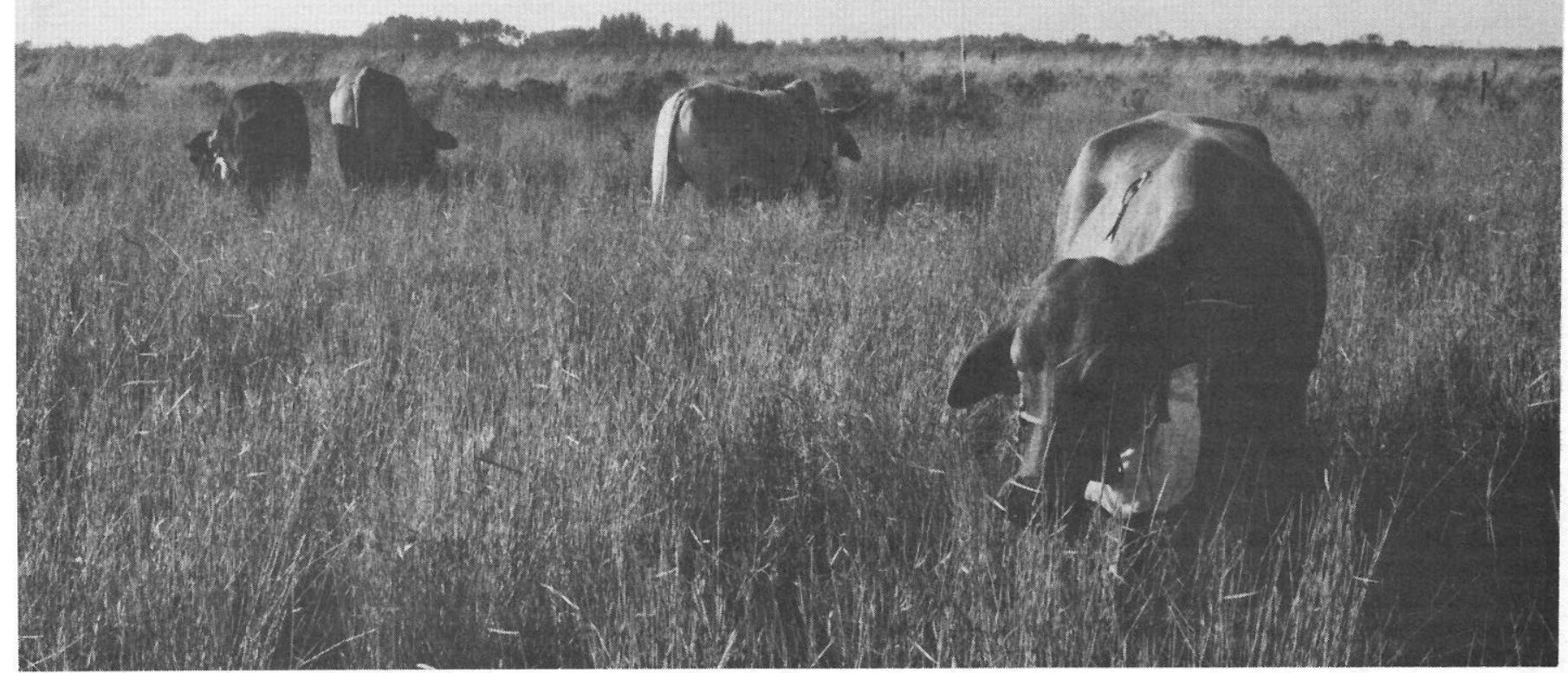

Fig. 2. Fresh water marsh ecological area on a South Florida flatwoods range near Ona. 
Each esophageal sample was spread on a screen tray, dried overnight $\left(50^{\circ} \mathrm{C}\right)$, ground (40 mesh), and mixed. A sub-sample from each steer for each collection day (320 unknown mixtures) was chlorine-bleached, washed over a 200-mesh screen, and mounted on 3 microscope slides. Tissues of major plants that grew on the study area were similarly ground and mounted for study as reference material. Identification of each species in the diet samples was based on epidermal characteristics, and the percentages of the dry weight in the diets were determined from relative particle densities of each identified plant (Sparks and Malechek 1968). Determinations were based on identification of tissue fragments in 20 microscope fields on each of the 3 slides.

Dry matter yield of creeping bluestem, Andropogon spp, maidencane, and forbs was determined before grazing each pasture. Three permanent transects were established in each of the 3 areas, and forage was cut at a specified distance to the left or right of the transect. Forage was cut by hand at the soil surface or the water level in the marsh. Cut forage was dried at $60^{\circ} \mathrm{C}$ for 48 to 72 hours then reweighed for oven-dry yield determination.

The percentages of each forage species from the unknown diets were averaged over steers for each collection date. The method of analysis used was for continuous proportions, that is, for percentages obtained when the basis is a continuous variable rather than counts, developed by Watson (1956). This method compares s groups of unit vectors. A unit vector is one for which the sum of the squared components is equal to unity.

Let $\mathrm{p}_{\mathrm{ijk}}$ be the proportion of Species $\mathrm{j}$ and Sample $\mathrm{k}$ from Group $\mathrm{i}, \mathrm{i}=1,2, \ldots, \mathrm{s} ; \mathrm{j}=1,2, \ldots, \mathrm{q}$; and $\mathrm{k}=1,2, \ldots, \mathrm{n}_{\mathrm{i}}$. Then the sample can be represented by a vector $V_{i k}=\left(p_{i l k}, p_{i 2 k}, \ldots, p_{i q k}\right)$. Since the total sample is partitioned in q components, $\Sigma_{j} p_{i j k}=1$ for each combination of $\mathrm{i}$ and $\mathrm{k}$. Thus, if square roots of the proportions are used, all vectors will be of unit length as required. For this reason the analysis was based on the square root of the proportions rather than the proportions themselves.

Since each vector is of unit length they can be represented by points on a sphere in q-dimensions. If no differences exist among the $s$ groups, these points should be randomly distributed on the sphere. When this is true, $\Sigma_{i} R_{i}-R$ should be small, where $R_{i}$ is the length of the resultant of the vectors for Group i, and R is the length of the resultant based on all vectors. The resultant of a set of vectors is simply the sum of components over the set of vectors.

To determine if the difference is small, $\Sigma_{i} R_{i}-R$ is compared to $N$ $-\Sigma_{i} R_{i}$, where $N=\Sigma_{i} n_{i}$ is the total number of vectors, using the ratio

$$
\frac{(N-s)\left(\Sigma_{i} R_{i}-R\right)}{(R-1)\left(N-\Sigma_{i} R_{i}\right)}
$$

where is approximately $\mathrm{F}$ with $(\mathrm{s}-\mathrm{l})(\mathrm{q}-\mathrm{l})$ and $(\mathrm{N}-\mathrm{S})(\mathrm{q}-\mathrm{l})$ degrees of freedom. If the observed ratio is greater than the critical value of $F$ at the desired significance level the null hypothesis that the s groups have the same proportions is rejected. Procedures have not yet been developed which will allow the testing of particular components within the vectors for significance.

\section{Results and Discussion}

\section{Available Plants}

The pastures contained 25 grasses, 10 sedges, 54 forbs and 20 shrubs. The pine-palmetto area contained 55 species, the transition area had 33 species, and the marsh area contained 19 species. Many plants grew on more than one of these areas.

Perennial grasses contributed the greatest portion of the dry matter yield of herbaceous vegetation on all areas (Table 1). About one half of the dry matter produced on the pine-palmetto area came from chalky bluestem, broomsedge and creeping bluestem. These grasses were distributed within the openings between the shrub and saw-palmetto (Fig. 1). Dominant grasses on the transition areas (Fig. 3) were bluestem and carpetgrasses, and together they yielded 290,850 , and $920 \mathrm{~kg} /$ ha on the summer, regrazewinter and winter-only pastures, respectively (Table 1). The dominant, almost exclusive plant on the marsh was maidencane (Fig. 2). Yields of maidencane ranged from 2,570 to $4,800 \mathrm{~kg} /$ ha of dry matter which resulted in the marsh being the most productive of the 3 areas.

Sedges were found almost exclusively on transition and marsh areas. These genera (Cyperus, Fimbristylis, Fuirena, Rhynchospora, and Scleria) did not comprise a major portion of the total dry matter yields. Individually they were a small part of the total plant

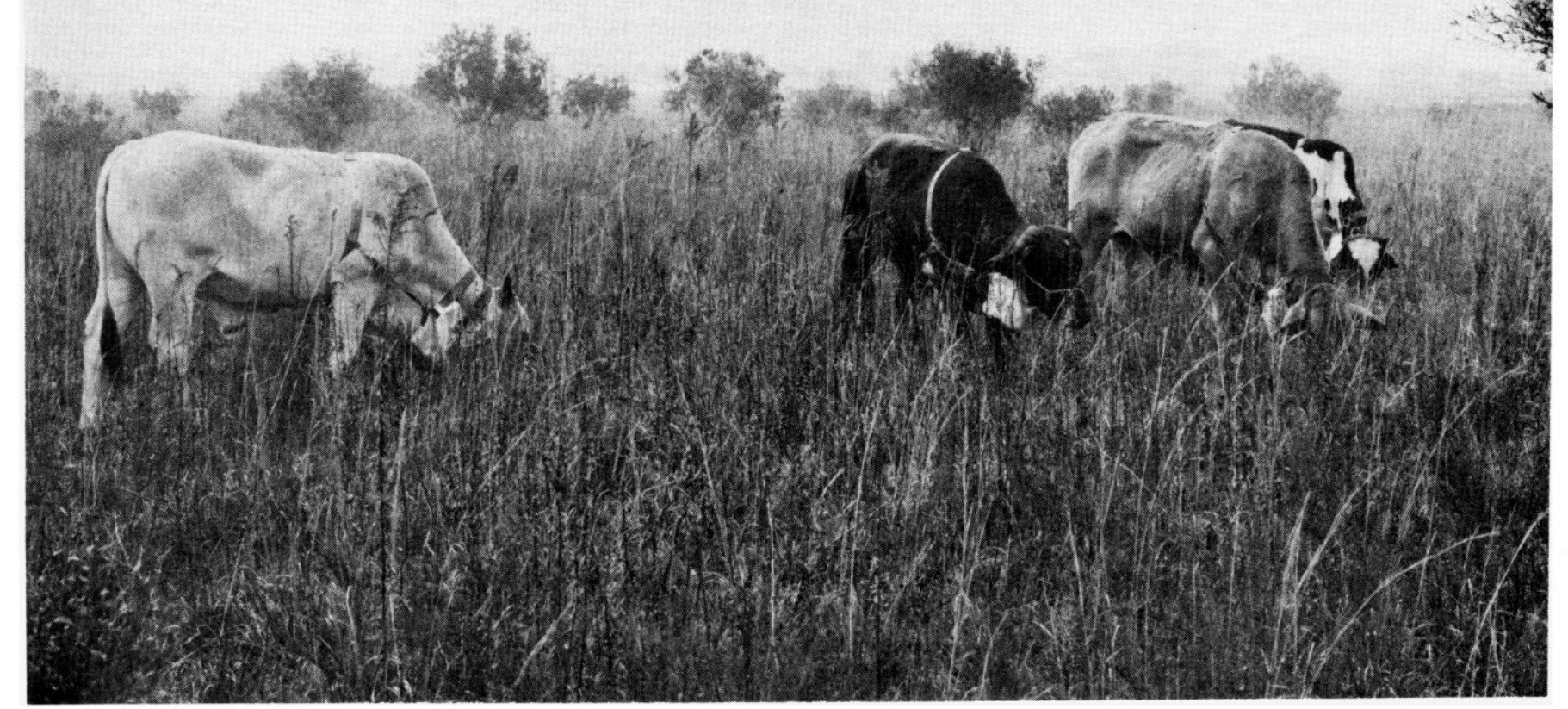

Fig. 3. Transition ecological area between pine-palmetto and fresh water marsh on a South Florida flatwoods range near Ona. 
Table 1. Dry matter yield (oven-dry) of the major grasees and forbs before graxing a pasture near Ona, Florida, $1984-1981$.

Pasture-

\begin{tabular}{|c|c|c|c|c|c|c|c|c|c|}
\hline \multirow[b]{2}{*}{ Forage } & \multicolumn{3}{|c|}{ Summer } & \multicolumn{3}{|c|}{ Regraze-winter } & \multicolumn{3}{|c|}{ Winter-only } \\
\hline & PP† & $\mathrm{T}$ & FM & PP & $\mathrm{T}$ & $\mathbf{F M}$ & PP & $\mathrm{T}$ & $\mathbf{F M}$ \\
\hline & & & & & $-\mathbf{k g} / \mathbf{h}$ & & & & \\
\hline \multicolumn{10}{|l|}{ Grasses } \\
\hline Chalky and broomsedge bluestem & 110 & 190 & $\mathbf{0}$ & 210 & 630 & 0 & 200 & 630 & 0 \\
\hline Creeping bluestem $\ddagger$ & 230 & 0 & 0 & 340 & 0 & 0 & 410 & $\mathbf{0}$ & 0 \\
\hline Maidencane & 8 & 8 & 2570 & 8 & 8 & 4800 & 8 & 8 & 3090 \\
\hline Carpetgrasses & 0 & 100 & 0 & i & $220^{\circ}$ & 0 & i & $290^{\circ}$ & 0 \\
\hline Other grasses & 490 & 220 & 8 & 490 & 750 & $\mathbf{0}$ & 430 & 970 & 200 \\
\hline Total grasses & 830 & 510 & $\overline{2570}$ & 1040 & 1600 & 4800 & 1040 & 1890 & 3290 \\
\hline \multicolumn{10}{|l|}{ Forbs } \\
\hline All species & 40 & 310 & 8 & 120 & 500 & $\mathbf{0}$ & 260 & 840 & 450 \\
\hline Ecological area totals & $870 b^{*}$ & $820 \mathrm{c}$ & $2570 \mathrm{~b}$ & $1160 \mathrm{a}$ & 2100 a & $4800 \mathrm{a}$ & $1300 \mathrm{a}$ & 2730 a & $3740 \mathrm{ab}$ \\
\hline $\begin{array}{l}\text { Weighed ecological totals } \\
\text { Average weighed pasture total }\end{array}$ & 610 & $\begin{array}{c}80 \\
1200 \mathrm{~b}+t\end{array}$ & 510 & 820 & $\begin{array}{c}210 \\
2010 \mathrm{a}\end{array}$ & 980 & 910 & 270 & $\begin{array}{c}740 \\
1920 \mathrm{a}\end{array}$ \\
\hline
\end{tabular}

PP, pine-palmetto; T, transition; FM, fresh marsh.

Found along the pine-palmetto/transition interface only, therefore considered a pine-palmetto species in this paper.

8 Trace.

- For comparison of means within ecological area. Means followed by the same letter are not different $(P<0.05)$.

\# Weighed according to percentage of area occupied by respective communities.

$\dagger$ Means on the same line followed by the same letter are not different $(P<0.05)$

Table 2. Average diet composition of esophageally fistulated steers graxing fatwoods range pastures initially in the summer and winter and regraxing the summer pasture in the winter, Ona, Florida.

\begin{tabular}{|c|c|c|c|c|}
\hline \multicolumn{2}{|c|}{ Plants } & \multicolumn{3}{|c|}{ Pasture-t } \\
\hline Common name & Genus-species & Summer & Regraze-winter & Winter-only \\
\hline $\begin{array}{l}\text { Grasses-sedges } \\
\text { Chalky bluestem } \\
\text { Broomsedge } \\
\text { Wiregrass } \\
\text { Carpetgrass } \\
\text { Low Panicums } \\
\text { Lovegrasses } \\
\text { Maidencane } \\
\text { Paspalums } \\
\text { Creeping bluestem } \\
\text { Indiangrass } \\
\text { Unidentified } \\
\text { Sedges }\end{array}$ & $\begin{array}{l}\text { Andropogon capillipes } \\
\text { Andropogon virginicus } \\
\text { Aristida stricta } \\
\text { Axonopus spp } \\
\text { Dichathelium spp } \\
\text { Eragrostis spp } \\
\text { Panicum hemitomon } \\
\text { Paspalum spp } \\
\text { Schizachyrium stoloniferum } \\
\text { Sorghastrum secundum } \\
\text { Cyperaceae }\end{array}$ & $\begin{array}{r}13 \\
1 \\
8 \\
2 \\
1 \\
1 \\
32 \\
8 \\
27 \\
8 \\
8 \\
8 \\
77\end{array}$ & $\begin{array}{r}\%-17 \\
1 \\
8 \\
6 \\
1 \\
8 \\
5 \\
2 \\
21 \\
0 \\
0 \\
3 \\
56\end{array}$ & $\begin{array}{r}11 \\
3 \\
2 \\
4 \\
1 \\
8 \\
7 \\
8 \\
19 \\
8 \\
8 \\
1 \\
48\end{array}$ \\
\hline $\begin{array}{l}\text { Forbs } \\
\text { Red root } \\
\text { Candy weeds } \\
\text { Meadow beauty } \\
\text { Golden rod } \\
\text { Yellow-eyed grasses } \\
\text { Unidentified }\end{array}$ & $\begin{array}{l}\text { Lachnanthes caroliniana } \\
\text { Polygala spp } \\
\text { Rhexia nuttalii } \\
\text { Solidago fistulosa } \\
\text { Xyris spp } \\
\\
\\
\end{array}$ & $\begin{array}{r}11 \\
1 \\
8 \\
8 \\
1 \\
8 \\
14\end{array}$ & $\begin{array}{r}8 \\
0 \\
8 \\
11 \\
12 \\
8 \\
23\end{array}$ & $\begin{array}{r}8 \\
0 \\
8 \\
8 \\
14 \\
1 \\
23\end{array}$ \\
\hline $\begin{array}{l}\text { Shrubs } \\
\text { Chokeberry } \\
\text { Gallberry } \\
\text { St. John's warts } \\
\text { Staggerbush } \\
\text { Sweet bay } \\
\text { Wax myrtle } \\
\text { Saw palmetto } \\
\text { Huckleberry }\end{array}$ & $\begin{array}{l}\text { Aronia arbutifolia } \\
\text { Ilex glabra } \\
\text { Hypericum spp } \\
\text { Lyonia spp } \\
\text { Magnolia virginicus } \\
\text { Myrica cerifera } \\
\text { Serenoa repens } \\
\text { Vaccinium myrsinites }\end{array}$ & $\begin{array}{l}8 \\
8 \\
1 \\
2 \\
0 \\
1 \\
5 \\
0\end{array}$ & $\begin{array}{l}1 \\
7 \\
1 \\
8 \\
1 \\
2 \\
9 \\
8\end{array}$ & $\begin{array}{r}8 \\
8 \\
8 \\
8 \\
8 \\
1 \\
20 \\
8\end{array}$ \\
\hline & Total & 9 & 21 & 29 \\
\hline
\end{tabular}

$\dagger$ Proportions of the diet components of cattle grazing summer pasture are different $(\mathbb{P}<0.01)$ from regraze winter and winter only pasture, but the regraze-winter and winter-only pastures are not different $(P<0.05)$.

8 Trace, $<1.0 \%$ of the diet. 
community in terms of biomass production.

Many of the forbs were annuals, and were present in the spring and summer. Unlike the grasses, these forbs were fragile and easily destroyed by weathering after maturity. The pine-palmetto and transition areas contained the greatest variety of forbs with 44 species out of 54. Forbs that contributed most to the pine-palmetto and transition area yields, respectively, were red root and golden rod, both of which formed colonies because of their rhizomatous growth habits. The forbs comprise 3 to $9 \%$ of the herbaceous yields on the pine-palmetto and 20 to $37 \%$ of the yield on the transition areas (Table 1).

Shrubs, particularly palmetto, were a major part of the pinepalmetto area, but there were no pine trees (Fig. 1). Foliar cover by palmetto averaged $38 \%$ on the pine-palmetto area, but the plant was absent on the marsh and transition areas (Fig. 2 and 3). Other major shrubs were gallberry and wax myrtle, which was found mostly on the transition area (Fig. 3).

\section{Cattle Diets}

\section{Season and Effects of Grazing}

The steers were known to have sampled about $39 \%$ of the available plant species. Diets of cattle grazing the summer pasture were different $(P<0.01)$ from diets of cattle grazing the regraze-winter and winter-only pastures, but diets of cattle grazing the regrazewinter and winter-only pastures were not different $(P<0.05)$ (Table 2 ). Because cattle were only allowed free choice in the ecological areas that they were forced to graze, care must be used in interpreting the data in Table 2. Differences in diets of cattle grazing on the pastures were based on similar time spent grazing each ecological area in each pasture.

The differences between summer and winter diets were due to overall changes in the proportions of grasses, forbs, and shrubs. The diets of cattle grazing the summer pasture declined by 21 to 29 percentage units in the proportions of grasses when compared to the regraze-winter and winter-only pasture, respectively. There was an increase of 9 percentage units in the amount of forbs and a 12 and 20 percentage unit increase in the proportion of shrubs in the diets of cattle grazing the summer and winter pastures, respectively.

Grasses and grass-likes made up $77 \%$ of the dry matter intake in the summer, but 56 and $48 \%$ from the regraze-winter and winteronly pastures (Table 2). A major species in the diet was considered to be one which accounted for $10 \%$ or more of the diet. Satisfying this requirement for the grasses were chalky and creeping bluestem, carpetgrass, and maidencane. The proportion of creeping, chalky, and broomsedge bluestem in the diet remained fairly constant from summer to winter on both regraze-winter and winteronly pastures, but maidencane consumption dropped significantly between summer $(32 \%$ ) and winter ( 5 and $7 \%$ on the regraze-winter and winter-only pastures). Carpetgrass use was slight in the summer, but did increase slightly on the transition during winter (Table 3).

Table 3. Comparison of diet composition of esophageally fistulated steers grazing three plant communities in summer (16 June to 26 Aug. 1980 ) and winter (12 Jan. to 18 March 1981) near Ona, Florida.

\begin{tabular}{|c|c|c|c|c|c|c|}
\hline \multirow[b]{3}{*}{ Plants } & \multicolumn{6}{|c|}{ Pasture- +} \\
\hline & \multicolumn{3}{|c|}{ Summer } & \multicolumn{3}{|c|}{ Wintert } \\
\hline & $\mathbf{P P}$ & $T$ & FM & $\mathbf{P P}$ & $\mathrm{T}$ & FM \\
\hline & & & - die & 6 & & \\
\hline \multicolumn{7}{|l|}{ Grasses-sedges } \\
\hline Chalky bluestem & 17 & 21 & 3 & 8 & 29 & 3 \\
\hline Broomsedge & 3 & 0 & 0 & 4 & 1 & $\S$ \\
\hline Wiregrass & $\S$ & 8 & $\S$ & 1 & 1 & $\$$ \\
\hline Carpetgrasses & 3 & 2 & $\S$ & 2 & 11 & $\dot{8}$ \\
\hline Low Panicums & 0 & 5 & 0 & 1 & 4 & i \\
\hline Lovegrasses & $\S$ & $\S$ & 1 & 0 & $\S$ & 1 \\
\hline Maidencane & $i$ & i & 91 & $\S$ & $\$$ & 20 \\
\hline Paspalums & $\S$ & 0 & $\S$ & $\S$ & 2 & $\S$ \\
\hline Creeping bluestem & 41 & 42 & $\dot{0}$ & 37 & 17 & 1 \\
\hline Indiangrass & 1 & 0 & 0 & 0 & $\S$ & 0 \\
\hline \multirow{2}{*}{$\begin{array}{l}\text { Unidentified grass } \\
\text { Sedges }\end{array}$} & $\S$ & 8 & 8 & $\S$ & $\S$ & 0 \\
\hline & $\S$ & $\S$ & $\mathbf{0}$ & $\S$ & $\S$ & 5 \\
\hline Total & 66 & 71 & 95 & 54 & 65 & 31 \\
\hline \multicolumn{7}{|l|}{ Forbs } \\
\hline Red root & 17 & 15 & 8 & 1 & 1 & 0 \\
\hline Candyweeds & 1 & 2 & i & 0 & 0 & 0 \\
\hline Meadow beauty & 8 & $\S$ & $\S$ & $\S$ & $\S$ & 0 \\
\hline Golden rod & $i$ & 0 & $\S$ & 2 & 11 & 15 \\
\hline Yellow-eyed grasses & 3 & $\S$ & $\dot{8}$ & 2 & 2 & 40 \\
\hline \multirow[t]{2}{*}{ Unidentified } & 8 & $\S$ & 0 & $\S$ & 1 & 1 \\
\hline & 22 & 17 & 1 & 5 & 15 & 56 \\
\hline \multicolumn{7}{|l|}{ Shrubs } \\
\hline Chokeberry & $\S$ & 8 & 8 & 0 & 1 & 8 \\
\hline Gallberry & $\S$ & 0 & 8 & 12 & 6 & 3 \\
\hline St. John's worts & $\S$ & 6 & 1 & $\$$ & $\S$ & 1 \\
\hline Staggerbrush & 3 & $\S$ & 0 & 1 & 0 & 0 \\
\hline Sweet bay & 0 & $\stackrel{\circ}{0}$ & 0 & 0 & $\S$ & 2 \\
\hline Wax myrtle & 2 & $\S$ & 1 & $\S$ & 4 & $\S$ \\
\hline Saw palmetto & 7 & 6 & 2 & 27 & 9 & 7 \\
\hline \multirow[t]{2}{*}{ Huckleberry } & 0 & 0 & 0 & 1 & 0 & 0 \\
\hline & 12 & 12 & 4 & 41 & 20 & 13 \\
\hline
\end{tabular}

$\nmid$ Results of the analysis imply the following differences among areas; Summer (FM) (PP,T); Winter (PP) (T) (FM), where areas within parenthesis are not different $(P<0.05)$. $\ddagger$ Average of regraze-winter and winter-only pastures. Diet composition of regraze winter not different $(P<0.05)$ from the winter-only pasture.

\$Trace, $<1.0 \%$ of the diet. 
These results are similar to the findings of other researchers (Thetford et al. 1971, Beck 1975, Bishop et al. 1975, Rosiere et al. 1975, Uresk and Rickard 1976, Durham and Kothmann 1977, Havstad et al. 1979, Johnson and Pearson 1981) who had found that a few grasses usually comprise the bulk of cattle diets. We believe that the cattle were not particularly selective in their choice of plants, because they would stop to graze in those places where they could apparently obtain a compromise between the most and best forage for the least effort. Any other grasses that were found in the collection bag were probably consumed at least in part, in the course of eating major species. This was not true for carpetgrass, because this plant had decumbent leaves and was shorter than the bluestem which shared its area. When the amount of carpetgrass increased in diet of cattle grazing in the spring, it was due to selectivity of the steers.

Creeping and chalky bluestem and maidencane have been recognized as higher yielding grasses when compared to wiregrass (Yarlett and Roush 1970, Roush and Yarlett 1973, Kalmbacher et al. 1981), and this study has demonstrated their importance in the diet of cattle. Fostering these grasses should be an objective of the proper management.

Forbs, although most abundant in the summer, contributed a smaller percentage to the total diet in summer as compared with winter (Table 2). Red root was eaten almost entirely in the summer, when it was available, along with candy weeds and meadow beauty. The content of forbs in the winter diet was higher than in summer diets due to 8 to $11 \%$ golden rod, which began growth from rhizomes in mid-February. Yelloweyed grass that had been carried over from the previous summer made up 12 to $14 \%$ of the winter diet. $X$. elliottii was consumed on the pine-palmetto area while $X$. fimbriata made up as much as 22 to $41 \%$ of the diet while the steers were grazing the marsh in the winter.

Shrubs were not a major part of the summer diet, but palmetto did comprise about $5 \%$ (Table 2). The saw palmetto inflorescence and, in late summer, palmetto berries were selectively eaten. In the winter palmetto made up 9 and $20 \%$ of the diet on the respective winter pastures when the tips of the fronds were eaten (sometimes back to the petiole). Gallberry was also eaten and, like palmetto, almost every winter collection contained a small amount. Both of these shrubs are ever-green and remained alive through the various frosts of the 1981 winter.

Other researchers (Galt et al. 1969, Wallace et al. 1972, Beck 1975, Durham and Kothmann 1977, and Vavra et al. 1977) have reported the seasonal use of forbs and shrubs. This is primarily due to relative availability of other forages. Our results on these subtropical pastures were consistent with the general findings of these investigators working in temperate locations.

\section{Ecological Area Effects}

Composition of diets of cattle grazing on the pine-palmetto and transition areas were not different $(P<0.05)$ from each other on the summer pasture, but the compositions of diets from the pinepalmetto and transition areas were different $(P<0.05)$ from diets from rhizomes in mid-February. Yellow-eyed grass that had been these shrubs are ever-green and remained alive through the various frosts of the 1981 winter.

The content of grasses in the summer diet was similar on the pine-palmetto and transition areas, but content of grasses in the diet was greater on the marsh where maidencane made up almost the entire diet (Table 3 ). On the 2 winter pastures, pine-palmetto and transition areas were similar in the amount of grasses in the diet, but grasses in the diets of cattle grazing the marsh declined from $95 \%$ in the summer to 31 and $32 \%$, respectively. The decrease in maidencane use was due to reduced palatability as a result of repeated frost. Creeping, chalky, and broomsedge bluestem remained green after frost, but maidencane top-growth was killed. Chalky bluestem was more abundant on the transition than on the pine-palmetto area, and the amount of this grass in the diet was greater on the transition than on the pine-palmetto area. The use of ow panicums and carpetgrass was greater on the transition area of the winter-only pasture. We believe that differences in the amounts of grass eaten on the various areas were due to relative abundance of the species. Sometimes the most abundant forage is not selected (Leigh and Mulham 1966), but in this study this only applied to maidencane in the winter.

There is an important management implication to be drawn from these data concerning the use of marsh sites. Maidencane should be used as summer pasture. Summer quality of maidencane was found to be better than that of other native grasses (Kalmbacher 1983); and grazing pastures with abundant or large marshes in the summer, when cattle relish maidencane, would be management with the greatest potential for red-meat production.

Consumption of forbs was greater on the pine-palmetto and transition areas in the summer as compared with the marsh (Table 3). The amount of forbs eaten on the pine-palmetto area declined in the winter, remained constant on the transition area and increased on the marsh. These trends were the result of a decreased in availability of red root on the pine-palmetto area, an increase in late winter-spring availability of golden rod on the transition, and seasonal acceptability (in lieu of maidencane) of red root on the marsh.

Shrubs were always available on the areas where they occurred. The increase in their use on the pine-palmetto area in the winter was attributed to a decrease in availability of forbs. Palmetto contributed $4 \%$ and $9 \%$ of diet dry matter from the marsh in the regraze-winter and winter-only pastures, respectively. This species did not grow on the transition or marsh areas, but steers grazed palmetto as they were hazed to the marsh and back.

\section{Conclusions}

Esophageal-fistulated steer diets were significantly different between summer and winter on a south Florida rangeland. Summer grazing of range did not affect steer selection for winter diets when the same pasture was regrazed. The differences between summer and winter pastures were mainly due to a decrease in the proportion of maidencane in the marsh diets, decrease in the proportion of red root on the pine-palmetto area, an increase in the proportion of shrubs in the pine-palmetto area diet, and an increase in yellow-eyed grass and golden rod on the transition and marsh. The changes in diet were the result of change in plant availability or palatability as in the case of maidencane, which was eaten almost exclusively on the marsh in the summer, but very little in the winter.

The differences in steer diets from the 3 ecological areas were the function of presence or absence of a species through site-plant compatability or through seasonal availability. Grasses, forbs and shrubs were all important pine-palmetto area diet components. Forbs and grasses were important on the wetter transition and marsh areas.

Several management inferences can be drawn from this research. First, chalky and creeping bluestem were major components of cattle diets in pine-palmetto and transition areas. Any management, such as chopping, resting (Yarlett 1965), or rotational grazing, which would foster their presence would be advantageous. Second, fresh marsh areas with dominant stands of maidencane should be used as a summer forage and not stock-piled for winter use. Third, forbs are seasonally available and their presence should be encouraged. This means careful use of certain herbicides and shrub control that allows them to compete on their respective areas. Fourth, shrubs are important in the winter diet, and they should occupy some of the range as a food source.

\section{Literature Cited}

Beck, R.F. 1975. Steer diets in Southeastern Colorado. J. Range Manage. 28:48-51. 
Bishop, J.P., J.A. Froseth, H.N. Verettoni, and C.H. Noller. 1975. Diet and performance of sheep on rangeland in semi-arid Argentina. J. Range Manage. 28:52-55.

Durham, A.J., Jr., and M.M. Kothmann. 1977. Forage availability and cattle diets on the Texas coastal prairie. J. Range Manage. 30:103-106.

Galt, H.D., B. Theurer, J.H. Ehrenreich, W.H. Hale, and S.C. Martin. 1969. Botanical composition of diets of steers grazing a desert grassland range. J. Range Manage. 22:14-19.

Havstad, K., R.D. Pieper, G.D. Donart, J.D. Wallace, E.J. Cordova, and E.E. Parker. 1979. Cattle diets on a fertilized blue grama upland range site. J. Range Manage. 32:398-401.

Hilmon, J.B. 1964. Plants of the Calossa experimental range. U.S. Forest Service Research Paper. SE-12. USDA Forest Service. Asheville, N.C.

Johnson, M.K., and H.A. Pearson. 1981. Esophageal, fecal and exclosure estimates of cattle diets on long leaf pine-bluestem range. J. Range Manage. 34:232-234.

Kalmbacher, R.S. 1978. Florida's range resources: A primary source of forage. Proceedings of the 35th Southern Pasture and Forage Crop Improvement Conference. Sarasota, FL.

Kalmbacher, R.S., F.G. Martin, and J.M.S. Andrade. 1981. Yield and quality of creeping bluestem as affected by time of cutting. J. Range Manage. 34:471-474.

Kalmbacher, R.S. 1983. Distribution of dry matter and chemical constituents in plant parts of four Florida native grasses. J. Range Manage. 36:298-301.
Leigh, J.H., and W.E. Mulham. 1966. Selection of diet by sheep grazing semi-arid pastures on the Riverine Plain. I. A bladder saltbush (Atriplex vesicania), cottonbush (Kochia apaylla) community. Aust. J. Exp. Agr. and Anim. Husb. 6:460-470.

Rosiere, R.E., R.F. Beck, and J.D. Wallace. 1975. Cattle diets on semidesert grassland: botanical composition. J. Range Manage. 28:89-93.

Roush, R.D. and L.L. Yarlett. 1973. Creeping bluestem compared with four other native range grasses. $J$. Range Manage. 26: 19-21.

Sparks, D.R., and J.C. Malechek. 1968. Estimating percentage dry weight in diets using a microscopic technique. J. Range Manage. 21:264-265.

Thetford, F.O., R.D. Pieper, and A.B. Nelson. 1971. Botanical and chemical composition of cattle and sheep diets on Pinyon-Juniper grassland range. J. Range Manage. 24:425-431.

Uresk, D.W., and W.H. Rickard. 1976. Diets of steers on a shrub-steppe rangeland in south central Washington. J. Range Manage 29:464-466.

Vavra, M., R.W. Rice, R.M. Hansen, and P.L. Sims. 1977. Food habits of cattle on shortgrass range in Northeastern Colorado. J. Range Manage. 30:261-263.

Wallace, J.D., J.C. Free, and A.H. Denham. 1972. Seasonal changes in herbage and cattle diets on sandhill grassiand. J. Range Manage. 25:100-104.

Watson, G.S. 1956. Analysis of dispersion on a sphere. Monthly notices of the Royal Astronomical Society, Geophysics supplement. 7:153-159.

Yarlett, L.L. 1965. Control of saw-palmetto and recovery of native grasses. J. Range Manage. 18:344-345.

Yarlett, L.L., and Roush, R.D. 1970. Creeping bluestem (Andropogon stolonifer). J. Range Manage. 23:117-122. 